\title{
Insulin-like growth factor-II gene expression in a rat insulin- producing beta-cell line (INS-1) is regulated by glucose
}

\author{
M. Asfari ${ }^{1}$, W. De ${ }^{1}$, M. Nöel ${ }^{1}$, P. E. Holthuizen ${ }^{2}$, P. Czernichow ${ }^{1}$ \\ ${ }^{1}$ INSERM CJF-9313, Hôpital Robert Debré, Paris, France \\ ${ }^{2}$ Laboratory for Physiological Chemistry, Utrecht University, Utrecht, The Netherlands
}

\begin{abstract}
Summary A highly differentiated rat glucose-responsive insulin producing cell line INS-1 expresses high levels of insulin-like growth factor-II (IGF-II). Basal levels of IGF-II gene mRNA were expressed in cells cultured at 1-6 mmol/l glucose. At glucose concentrations of $10-20 \mathrm{mmol} / 1$, IGF-II mRNA was increased more than threefold after $44 \mathrm{~h}$ of incubation. Levels of IGF-II mRNA in INS- 1 cells incubated at 5.6 and $20 \mathrm{mmol} / 1$ glucose in the presence of $4 \mu \mathrm{g} / \mathrm{ml}$ actinomycin $\mathrm{D}$ are comparable and are not reduced during $20 \mathrm{~h}$ of treatment, indicating the high stability of IGF-II mRNA in this cell line. From the three rat IGF-II promoters, promoter 3 is by far the most active in INS-1 cells. The IGF-II promoter 3 activity and IGF-II mRNA production at high glucose concentrations increased threefold over their respective levels at low glucose concentration, suggesting that the glucose-induced IGF-II gene expression in this
\end{abstract}

beta-cell line might be transcriptionally controlled. The up-regulation of IGF-II mRNA by glucose was not due to the increased intracellular cyclic AMP levels or protein kinase $\mathrm{C}$ activation. A protein kinase $\mathrm{C}$ activator had no effect on IGF-II gene expression, and an adenylate cyclase activator (forskolin), suppressed the stimulatory effects of glucose on the IGF-II mRNA. Under all the experimental conditions examined, the IGF-II and insulin genes were differentially regulated in INS-1 cells. The IGF-II gene expression and DNA synthesis, however, were regulated in parallel, suggesting that these two cellular activities are closely associated. [Diabetologia (1995) 38: 927-935]

Key words Beta cells, insulin-like growth factor II, insulin, glucose, gene expression.
Insulin-like growth factors (IGF-I and -II) are regulatory peptides of about $7.5 \mathrm{kDa}$, involved in the proliferation and/or differentiation of numerous cell types [1-6]. IGFs are members of the larger family of insulin-related peptides (insulin, IGF-I and -II, and relaxin) exerting their activities mainly through

Received: 18 November 1994 and in revised form: 27 February 1995

Corresponding author: Dr. M. Asfari, INSERM CJF-9313, Batiment Ecran 3 éme, Hôpital Robert Debré, 48 Bld. Sérurier, F-75019 Paris, France

Abbreviations: CM, Complete medium; IGF-II, insulin-like growth factor-II; PBS, phosphate buffered saline; SFM, serum-free medium; PMA, phorbol 12-myristate 13-acetate; HEPES, 4-(2-hydroxyethyl)-1-piperazineethane-sulphonic acid; ACC, acetyl CoA carboxylase. endocrine, autocrine or paracrine modes of action [7-9]. IGFs bind to IGF type-1, type-2 (IGF-II/cation-independent mannose 6-phosphate) and insulin receptors, which are present in most tissues. The major activities of both IGFs, however, are through the IGF type-1 receptor $[1,7,10-12]$. IGFs and insulin are believed to diverge from a common gene, and apart from structural similarities, they exert similar activities on different cell types [7, 13, 14]. While the biological role of IGF-I, after birth and during adulthood, is well-established, IGF-II is believed to be more effective during fetal development [15]. In rats, IGF-II gene expression is limited to the fetal life in most tissues, including liver. Among the exceptions are the choroid plexus, leptomeninges [16, $17]$, and islet beta cells of the endocrine pancreas $[18,19]$. 
Islet cells produce IGF-I and -II and secrete the two peptides in the culture medium [20-24]. IGF-I has been reported to be present in human [21] and rat [25] fetal islet beta cells. In a recent report [19], using immunohistochemical techniques it has been demonstrated that IGF-II in the adult human, dog, and rat islets, is coexpressed with insulin, while IGFI has been detected in glucagon- and/or somatostatin-producing cells $[19,25]$. In a report using Northern blot techniques, no IGF-I mRNA was detected in rat islets [26]. The IGF-II gene, in humans and rodents, is closely linked to the loci for insulin $[14,27$, 28]. These observations have raised the question as to whether the IGF-II and insulin genes are co-regulated. The fact that IGF-II is expressed in fetal and adult islet tissue suggests a possible important role for this peptide as a beta-cell autocrine growth and/ or differentiation regulatory hormone. Its regulation, therefore, during intrauterine life and after birth, may have an impact on maturation and proper functioning of the islets after birth.

The goal of the present work was to investigate the regulation of the IGF-II gene expression in beta cells. As a model, we chose a highly differentiated rat insulin producing cell line (INS-1) which exhibits many properties of normal beta cells, including: response to glucose in the physiological range [29], expression of glucose transporter-2, glucokinase [30], and growth hormone and prolactin receptor genes [31] at levels comparable to those of normal islets. Here we have demonstrated that INS-1 cells express the IGFII gene, which is regulated by glucose; and while variation in IGF-II gene expression parallels DNA synthesis, it markedly differs from that of insulin gene expression.

\section{Materials and methods}

Hormones and chemicals. Recombinant IGF-II was a gift of Kabi Pharmacia (Stockholm, Sweden); ${ }^{125}$ I-IGF-II was purchased from Amersham (Les Ulis, France). Unless stated otherwise, all the chemicals and reagents were purchased from Sigma (St. Quentin Fallavier, France).

Cell culture. INS-1 cells were maintained in complete medium (CM), containing RPMI/1640, $2 \mathrm{mmol} / 1$ glutamine, $100 \mathrm{U} / \mathrm{ml}$ penicillin, $100 \mu \mathrm{g} / \mathrm{ml}$ streptomycin, $1 \mathrm{mmol} / \mathrm{l}$ sodium pyruvate, $10 \%$ heat-inactivated fetal calf serum, $10 \mathrm{mmol} / \mathrm{l} \mathrm{HE}$ $\mathrm{PES}$, and $50 \mu \mathrm{mol} / 12$-mercaptoethanol, at $37^{\circ} \mathrm{C}$ in a humidified atmosphere with $5 \% \mathrm{CO}_{2}$ as previously described [29]. Specific culture conditions for each experiment are described in Results.

RNA extraction and Northern blot analysis. Cells were seeded into $100-\mathrm{mm}$ tissue culture plates and at the end of the incubation period the plates were chilled on ice and washed once with phosphate-buffered saline (PBS). RNA was isolated in urealithium chloride [32]. For RNA preparation from rat liver and muscle the fresh tissues were washed in ice-cold PBS and cut into small pieces. About $300 \mathrm{mg}$ of tissue was transferred into
$15 \mathrm{ml}$ of ice-cold urea-lithium chloride, homogenized, and RNA was then purified.

Total RNA $(20 \mu \mathrm{g})$ was denatured in formamide/formaldehyde at $65^{\circ} \mathrm{C}$ for $10 \mathrm{~min}$ and fractionated on formaldehyde $(2.2 \mathrm{~mol} / \mathrm{l})-1 \%$ agarose gel, blotted onto a nylon membrane (Hybond, Amersham) and UV-cross-linked. Blots were hybridized with $\alpha^{32} \mathrm{P}$-labelled cDNA probes overnight at $42^{\circ} \mathrm{C}$ in a solution containing $5 \times \mathrm{SSPE}$ (sodium salt phosphate EDTA), $5 \times$ Denhardt's solution, $0.1 \%$ sodium dodecyl sulphate (SDS), and $50 \%$ formamide. After hybridization the filters were washed twice in a solution of $2 \times$ SSC, $0.1 \%$ SDS for $15 \mathrm{~min}$ at room temperature and once in the same solution at $45^{\circ} \mathrm{C}$ for $60 \mathrm{~min}$. The filters were exposed to RX film (Fuji Medical X-ray film) at $-70^{\circ} \mathrm{C}$ using intensifying screens. The mRNAs on autoradiograms were quantified by scanning densitometry (Shimadzu Dual-wavelength TLC Scanner CS-930, Kyoto, Japan).

cDNA probes. The probes were human placental IGF-II cDNA insert (663-base pair) containing 5'-untranslated region, the entire coding region, and part of the $3^{\prime}$-untranslated region [33]; rat insulin I cDNA [34], and beta-actin [35]. For control of RNA loading, $\left[\gamma^{32} \mathrm{P}\right]$ ATP-labelled oligonucleotides complementary to $18 \mathrm{~S}$ ribosomal RNA [36] were used.

Rat IGF-II reporter gene constructs. Rat IGF-II promoter fragments were cloned into the promoterless firefly luciferase gene containing vector pSLA3 [37]. The rat promoter P1 fragment $(-499 /+213$, relative to the transcription initiation site $)$, was subcloned as a SacI/SalI fragment into pSLA3, resulting in construct RAP1. The rat promoter P2 construct, RAP2, contained a 1304 nt long BamHI/Sall $(-1164 /+140)$, cloned directly into pSLA3. Rat promoter P3 was cloned by means of PCR, containing a 884 nt promoter P3 fragment $(-809 /+75)$, flanked by BamHI/Sall sites, resulting in construct RAP3.

Transient transfection and luciferase expression assay. Cells were cultured in 12 -well culture plates at $0.5 \times 10^{6}$ cells $\cdot \mathrm{ml}^{-1}$ per well and incubated for $72 \mathrm{~h}$ in CM. They were washed with PBS and preincubated at $5 \mathrm{mmol} / 1$ glucose, in pyruvate and serum-free-medium (SFM), for $41 \mathrm{~h}$. They were then transfected using LipofectAMINE Reagent (GIBCO BRL, Paris, France) at $5 \mathrm{mmol} / \mathrm{l}$ glucose, for $7 \mathrm{~h}$ and incubated in fresh SFM ( $2 \mathrm{ml}$ per well) at different glucose concentrations for $48 \mathrm{~h}$. For each transfection assay $400 \mathrm{ng}$ plasmid DNA per million cells was used. At the end of the incubation period cells were harvested in $250 \mu$ lysate buffer [38], from which $200 \mu 1$ was used for detection of luciferase activity (Luamt LB 9501 with injector, Berthold s.a.r.1., Elancourt, France), and $50 \mu \mathrm{l}$ for determination of protein content (Bio-Rad Dc Protein Assay Kit; Bio-Rad Laboratories, Richmond, Calif., USA). At each culture condition the luciferase activity was normalized for the total protein. All constructs were tested in triplicate for each culture condition.

IGF-II assay. INS-1 cells were seeded into $60-\mathrm{mm}$ tissue culture plates in CM for $72 \mathrm{~h}$. They were washed with PBS and preincubated in SFM and $5 \mathrm{mmol} / \mathrm{l}$ glucose for $48 \mathrm{~h}$. The preincubation medium was changed with fresh SFM containing $8 \mathrm{mmol} / 1$ glucose and then incubated for a further $48 \mathrm{~h}$. At the end of the incubation period, the released IGF-II in the culture medium and in the cell extract (acid-ethanol, $0.15 \mathrm{~mol} / 1$ $\mathrm{HCl}$ in $75 \%$ ethanol at $-20^{\circ} \mathrm{C}$ ) were separated from the binding proteins as previously described [39]. Briefly, the lyophilized culture medium or the cell extract were separated from binding proteins in acidic solution $(1 \mathrm{~mol} / 1$ acetic acid, 0.15 
$\mathrm{mol} / \mathrm{l} \mathrm{NaCl}, 0.1 \%$ bovine serum albumin) on a $1.5 \times 75-\mathrm{cm} \mathrm{col-}$ umn of Ultrogel AcA 54 (LKB-IBF, Villeneuve-la-Garenne, France). The eluted IGF-II was lyophilized, desalted on a Sephadex G-25 column (PD-10; Pharmacia, Uppsala, Sweden) and measured by a competitive protein-binding assay using binding proteins prepared from human cerebrospinal fluid which have a selective affinity for IGF-II as described previously [40].

Thymidine incorporation assay. For the assessment of cell growth, cells were cultured in $1 \mathrm{ml}$ of $\mathrm{CM}$ at $10^{5}$ cells per well in 24-well culture plates for $48-72 \mathrm{~h}$. The cells were then washed with PBS and preincubated for $48 \mathrm{~h}$ in SFM. After this period, the medium was removed and cells were incubated in $1 \mathrm{ml} \mathrm{SFM}$ at different glucose concentrations. Depending on the experimental protocol, the rate of the DNA replication was assessed by addition of 1 or $2 \mu \mathrm{Ci}{ }^{3} \mathrm{H}$-thymidine (Amersham) per well, followed by 7 - or 2 -h incubation, respectively. The thymidine incorporation was stopped by addition of $1 \mathrm{mmol} / \mathrm{l}$ ascorbic acid and incorporated radioactivity was determined as previously described [41].

\section{Results}

Expression of IGF-II gene in INS-1 cells. We assessed the levels of expression of IGF-II in the INS-1 cell line. As a control we used fresh female adult Wistar rat liver and muscle tissues. As is illustrated in Figure 1 , INS-1 cells express high levels of IGF-II. Multiple IGF-II mRNAs were found with a predominant mRNA species of about 3.6 kilobases $(\mathrm{kb})$ and three minor species of about $2.2,1.6$, and $1.3 \mathrm{~kb}$. No IGFII mRNA was detected in the liver and muscle tissues, consistent with the previous reports that IGF-II is not expressed in most of the adult rat tissues. The IGF-II content of INS-1 cells, cultured for $48 \mathrm{~h}$ in SFM at $8 \mathrm{mmol} / 1$ glucose, was $2.45 \pm 0.28 \mathrm{ng}$ per million cells and the released IGF-II in the culture medium was $0.75 \pm 0.08 \mathrm{ng}$ per million cells.

Regulation of IGF-II mRNA levels by glucose. Glucose is the principal beta-cell secretagogue and nutrient, and is suggested to have a central role in the regulation of beta-cell proliferation [42]. To assess whether glucose plays a role in IGF-II gene expression, the effect of glucose on the IGF-II mRNA levels was determined. Basal levels of IGF-II mRNA were detected in INS-1 cells cultured at glucose concentrations of 1-6 mmol/1 (Fig. 2A). The increase in IGF-II mRNA levels was observed in cells that were cultured at $8 \mathrm{mmol} / \mathrm{l}$ reaching maximal levels at 10 $20 \mathrm{mmol} / 1$ glucose $(3.2 \pm 1.7$ fold increase, the mean of eight separate experiments). The IGF-II mRNA increase could be detected $25 \mathrm{~h}$ after incubation with glucose and gradually increased up to $40 \mathrm{~h}$ (Fig. 2B).

Differential glucose effects on insulin and IGF-II gene expression. It has been postulated that since insulin and IGF-II genes are tandemly located on rat chromosome 1, and also, since IGF-II was found only in the

\section{IGF-II}

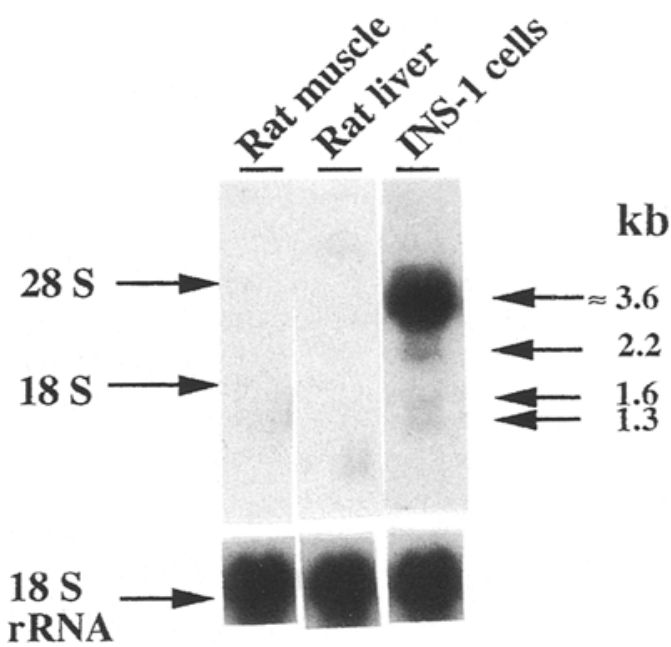

Fig. 1. Expression of IGF-II in INS-1 cells. Cells were cultured in CM for 5 days, washed with PBS and RNA was extracted (Materials and methods). Total RNA (20 $\mathrm{g}$ ) from INS-1 cells, rat liver and muscle tissue was blotted onto nylon membrane and hybridized to a human IGF-II cDNA probe

beta cells of the rat islets, both genes may be subject to the same regulatory mechanism. To test this hypothesis, we hybridized RNAs obtained from cells that were incubated at different glucose concentrations for 48 and $72 \mathrm{~h}$, to both IGF-II and insulin cDNA probes. As is shown in Figure 3 both genes were regulated by glucose; however, the optimal glucose concentrations for maximal expression of each gene were markedly different. While the insulin gene was highly expressed at $5 \mathrm{mmol} / \mathrm{l}$ glucose, the IGF-II gene was only expressed at basal levels. Conversely, at $15 \mathrm{mmol} / \mathrm{l}$ glucose, the IGF-II gene was highly expressed, while the insulin gene was down-regulated.

Differential effects of protein-kinase $C$ and cyclic $A M P$ on IGF-II and insulin gene expression. Part of the effect of glucose on beta-cell function, such as insulin release, is believed to be mediated by the rise of intracellular cyclic AMP and/or activation of the protein kinase $C$ system [43, 44]. To assess whether glucose-induced IGF-II gene expression falls into the same pattern, we examined the IGF-II gene expression at low and high glucose concentrations in the presence of forskolin (an adenylate cyclase activator) and PMA (phorbol 12-myristate 13-acetate), a protein-kinase $\mathrm{C}$ activator. As is demonstrated in Figure 4, PMA has no effect on IGF-II gene expression, at low or high glucose concentrations, and forskolin exhibits a strong inhibitory effect on IGF-II mRNA accumulation at high glucose concentrations (more than $50 \%$ inhibition). The same factors (forskolin and PMA) exerted completely different ef- 


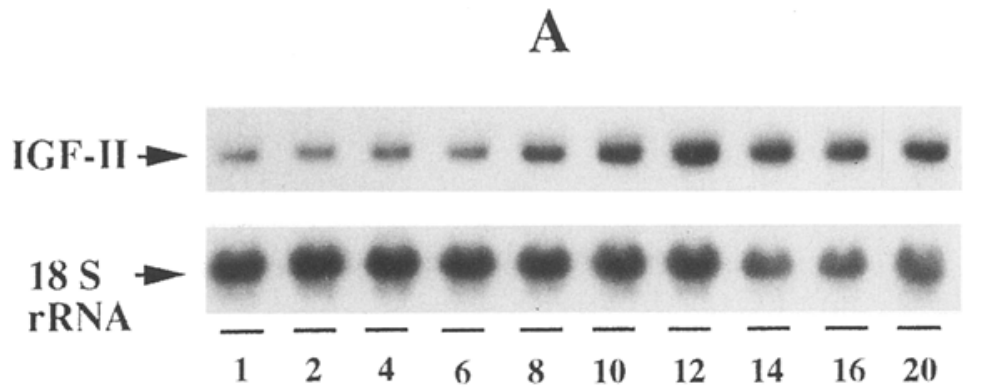

Glucose $(\mathrm{mmol} / \mathrm{l})$

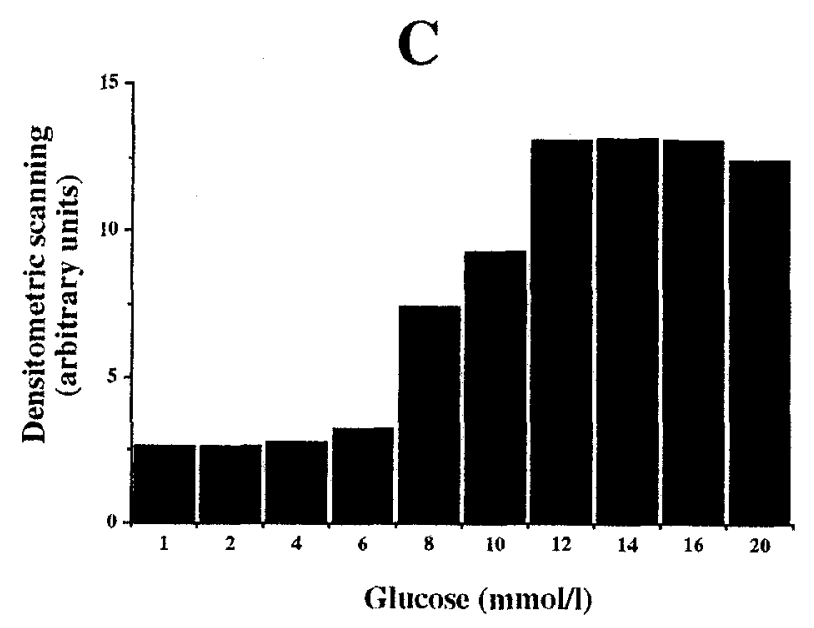

\section{Incubation period}

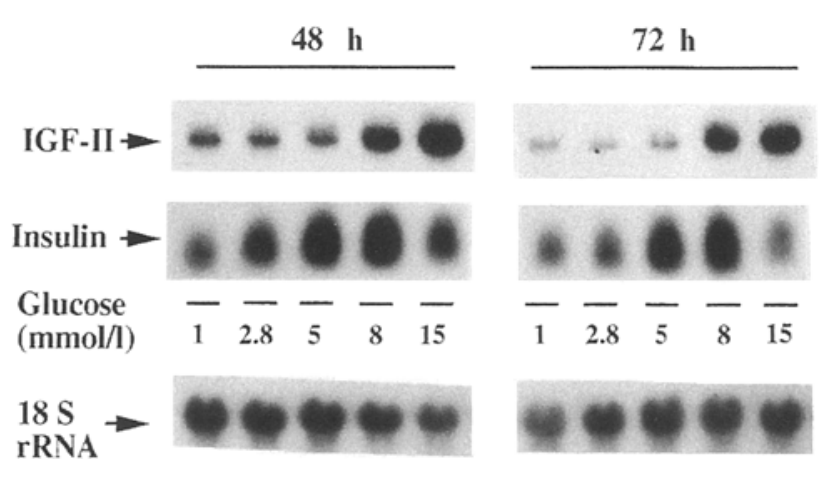

Fig.3. Glucose effect on IGF-II and insulin gene expression. Cells were cultured in $\mathrm{CM}$ for 5 days, then washed and incubated in medium at varying glucose concentrations. RNA was extracted at 48 and $72 \mathrm{~h}$ after incubation and hybridized simultaneously to the IGF-II and insulin cDNA probes

fects on insulin gene expression under identical conditions (Fig.4). At high glucose concentrations insulin mRNA levels were increased in the presence of forskolin or PMA, and at low glucose, forskolin was still effective in insulin mRNA up-regulation.

Effects of glucose, PMA and forskolin on cell proliferation. IGF-II is an autocrine growth factor in many

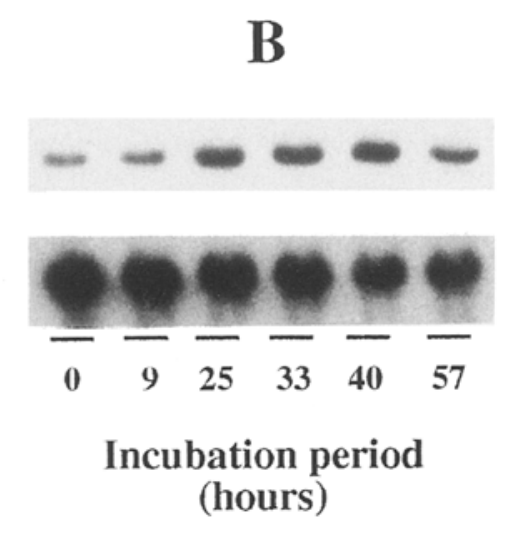

(hours)

Fig. 2. (A-C) Glucose effect on IGF-II gene expression. Cells were cultured in CM for 5 days, then washed with PBS and preincubated in serum-free medium (SFM) at $5 \mathrm{mmol} / \mathrm{l}$ glucose for $48 \mathrm{~h}$. They were then incubated in the same medium at varying glucose concentrations for $40 \mathrm{~h}$ (A dose effect), or at $15 \mathrm{mmol} / \mathrm{l}$ glucose for different periods of time (B time effect). RNA was extracted and hybridized to the IGF-II cDNA probe. The data of densitometric scanning of the autoradiogram (arbitrary units) of the dose response effects, normalized to the $18 \mathrm{~S}$ rRNA are presented (C)

cell types [7-9]. To determine whether a correlation between the regulation of the IGF-II gene expression and cell proliferation could be detected, INS-1 cell proliferation was determined under the same conditions as used for the determination of IGF-II mRNA regulation. As an indication of cell proliferation, we assessed the rate of ${ }^{3} \mathrm{H}$-thymidine uptake. As is illustrated in Figure 5A, B, glucose increased the thymidine uptake of INS-1 cells in a dose-and time-dependent manner. The maximal thymidine incorporation was reached at $15 \mathrm{mmol} / \mathrm{l}$ glucose and the significant thymidine uptake above basal level ( $5 \mathrm{mmol} / 1$ glucose) was observed after $26 \mathrm{~h}$ incubation at high glucose. The thymidine uptake at various glucose concentrations in the presence of PMA was identical to that of the control, but it was markedly reduced in the presence of $10 \mu \mathrm{mol} / \mathrm{l}$ forskolin at high glucose concentrations (Fig. 5B).

Stability of IGF-II mRNA in INS-1 cells. To determine the stability of IGF-II mRNA, cells were incubated at low $(5 \mathrm{mmol} / \mathrm{l})$ and high $(20 \mathrm{mmol} / \mathrm{l}) \mathrm{glu}-$ cose concentration in the presence of $4 \mu \mathrm{g} / \mathrm{ml}$ of the RNA synthesis inhibitor actinomycin D. RNA was extracted at different time intervals and hybridized to the cDNA probes of IGF-II and $\beta$-actin (as a control). It was found that the levels of IGF-II mRNAs were the same at both glucose concentrations and 

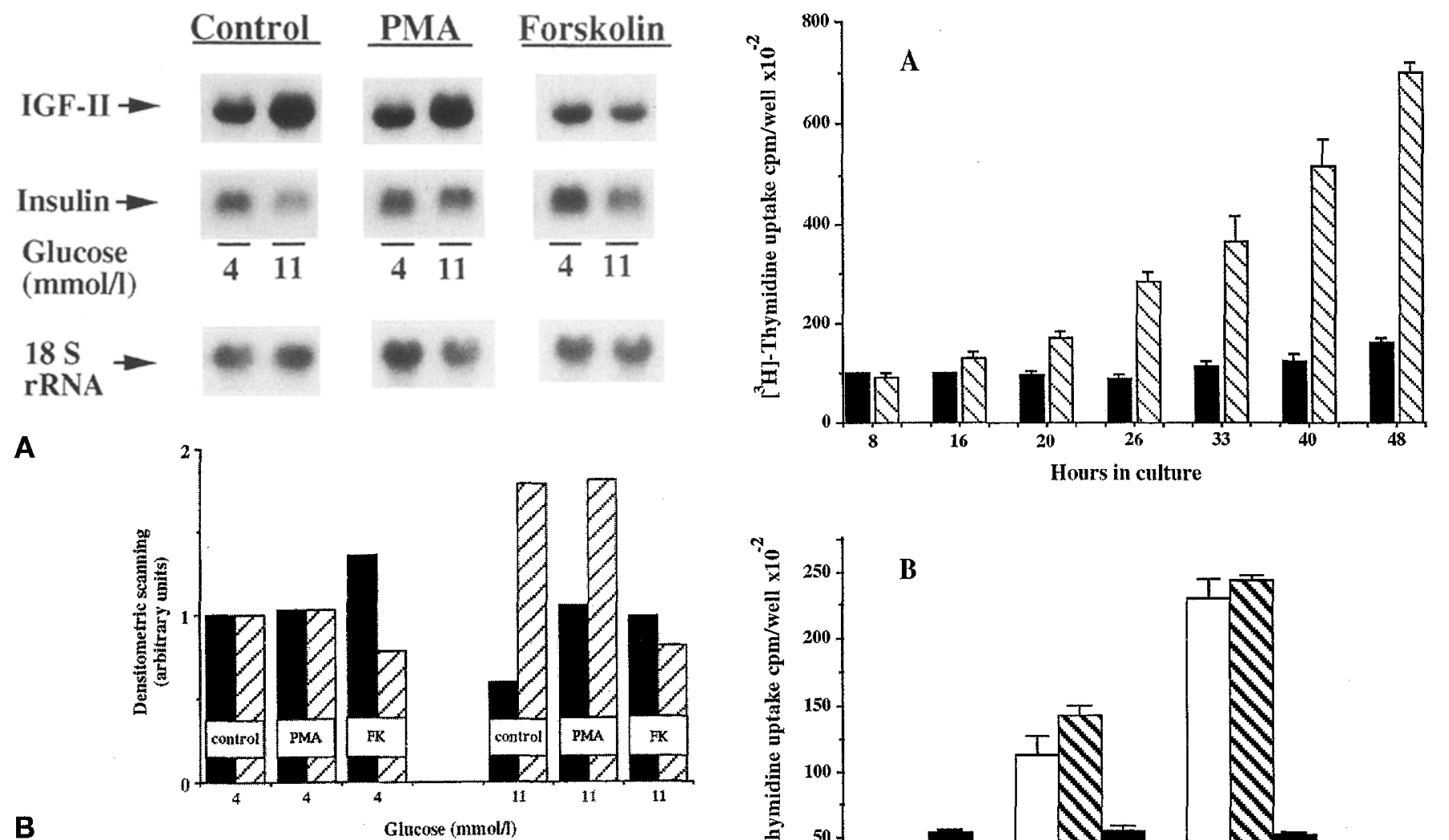

Fig. 4. (A, B) Forskolin, and PMA effects on IGF-II and insulin gene expression. Cells were cultured and preincubated as explained in the legend of Figure 2. They were then incubated in SFM at varying glucose concentrations in the presence of PMA $(0.1 \mu \mathrm{mol} / \mathrm{l})$ or forskolin $(10 \mu \mathrm{mol} / \mathrm{l})$. A Northern blot of RNA extracted after $40 \mathrm{~h}$ incubation and hybridized to IGFII and insulin cDNA probes. The glucose concentrations (4 and $11 \mathrm{mmol} / \mathrm{l}$ ) reflect the actual concentrations at the time of RNA extraction, the starting concentrations were 5.6 and $15 \mathrm{mmol} / \mathrm{l}$. B The scanning data of both insulin ( $\square$ ) and IGFII (Q/ mRNA normalized to the $18 \mathrm{~S}$ rRNA are presented. This is representative of three separate experiments

did not vary during $20 \mathrm{~h}$ of actinomycin $\mathrm{D}$ treatment (Fig. 6). However, expression of the control gene, $\beta$ actin mRNA, which has a half-life of less than $8 \mathrm{~h}$ [45] was reduced to about 50 and $20 \%$ at both glucose concentrations after 9 and $20 \mathrm{~h}$ incubation, respectively. This is consistent with a previous report on the high stability of IGF-II mRNA in BRL 3A cells [45]. The apparent slight increase of IGF-II mRNAs at 9 and $20 \mathrm{~h}$ incubation in comparison to $3 \mathrm{~h}$ is due to the difference in the total RNA loading (data not shown).

Transient expression of IGF-II promoters. The rat IGF-II gene is transcribed from three different promoters (P1, P2 and P3). In order to determine which of the three rat promoters could be activated in this beta-cell model, we transfected the INS-1 cells with plasmids containing the three rat IGF-II promoters fused to the luciferase reporter gene. Each construct was transfected in triplicate. As is illustrated in Fig-

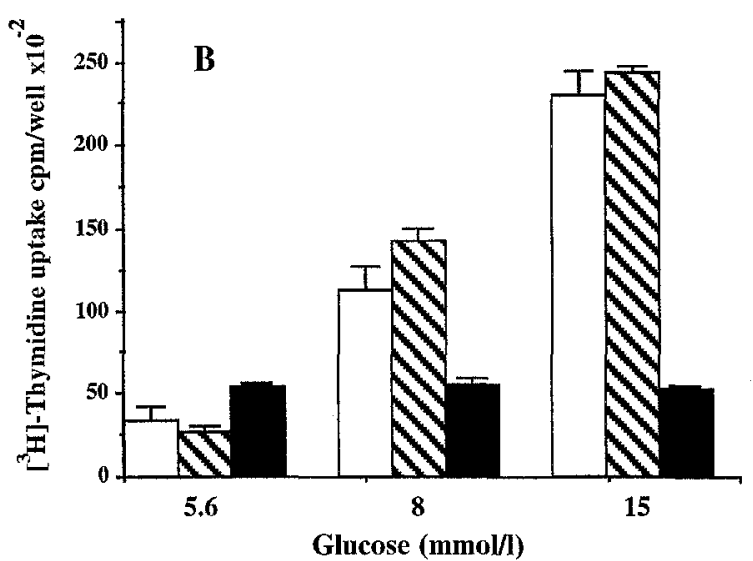

Fig. 5. (A, B) Glucose, forskolin and PMA effects on INS-1 cell DNA synthesis. Cells were cultured in 24-well culture plates and incubated for $72 \mathrm{~h}$ in $\mathrm{CM}$. The cells were then washed with PBS and preincubated in SFM and $5 \mathrm{mmol} / \mathrm{l}$ glucose for $48 \mathrm{~h}$. A The preincubation medium was replaced by SFM, containing $5(\square)$ or $15(\mathbb{M m o l} / \mathrm{l}$ glucose. At different time intervals cells were pulsed with $2 \mu \mathrm{Ci}{ }^{3} \mathrm{H}$-thymidine per well (triplicate well for each culture condition) for $2 \mathrm{~h}$ (results of two independent experiments). B The preincubation medium was removed and cells were incubated in SFM containing varying glucose concentrations (control $\square$ ) and $0.1 \mu \mathrm{mol} / \mathrm{l}$ PMA $(\square)$, or $10 \mu \mathrm{mol} / 1$ forskolin $(\square)$ for $40 \mathrm{~h}$. Cells were pulsed with $1 \mu \mathrm{Ci}{ }^{3} \mathrm{H}$-thymidine per well (triplicate well for each culture condition) for $7 \mathrm{~h}$ (results of four independent experiments)

ure 7, the rat IGF-II P3 is by far more active than the other two promoters, at all glucose concentrations, in this cell line, indicating that the $3.6 \mathrm{~kb}$ mRNA is transcribed from the IGF-II P3. The IGFII P3 activity in transfected INS-1 cells incubated at $15 \mathrm{mmol} / \mathrm{l}$ glucose was $3.13 \pm 0.38$ and $1.6 \pm 0.21$ times higher than the levels found in cells incubated at 5 and $25 \mathrm{mmol} / \mathrm{l}$ glucose, respectively. 


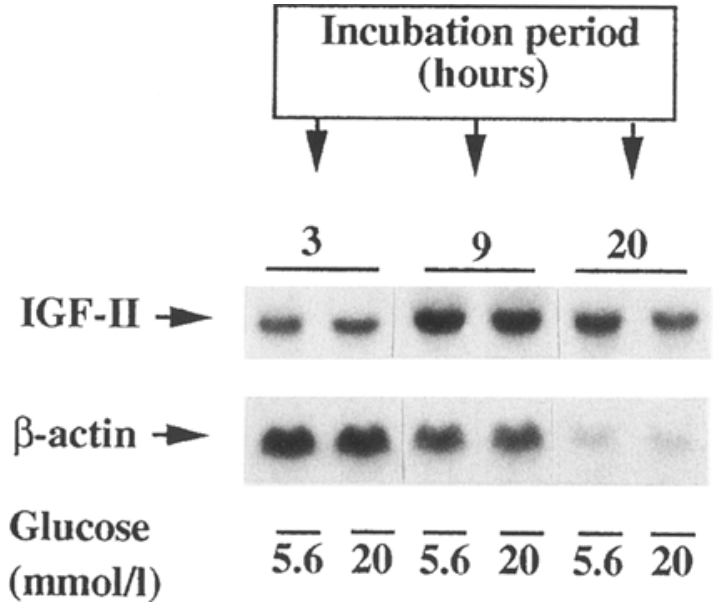

Fig.6. IGF-II gene expression under actinomycin D treatment. Cells were cultured in CM for 5 days, then washed with PBS and incubated in medium containing $0.1 \%$ serum (to increase the cell survival), $4 \mu \mathrm{g} / \mathrm{ml}$ actinomycin $\mathrm{D}$ and 5.6 or $20 \mathrm{mmol} / 1$ glucose, respectively. RNA was extracted at different time intervals and hybridized to IGF-II and $\beta$-actin cDNA probes

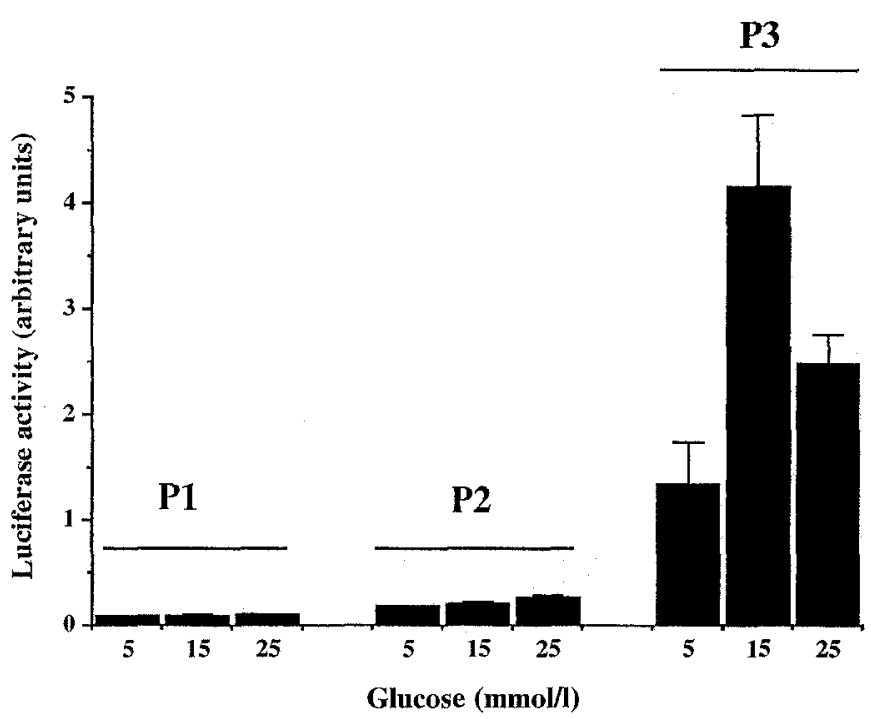

Fig. 7. Transient transfection of the rat IGF-II promoter constructs. Cells were cultured in 12 -well culture plates at $0.5 \times 10^{6}$ cells. $\mathrm{ml}^{-1}$ per well and transfected with plasmids carrying IGF-II promoters (P1, P2, P3) fused to firefly luciferase reporter gene (Materials and methods). The cells were then incubated in fresh medium at different glucose concentrations for $48 \mathrm{~h}$. At each culture condition the luciferase activity was normalized with the total protein content and all the constructs were tested in triplicate experiments. The luciferase activities at each glucose concentration were normalized for the total protein at each culture condition. The values are mean \pm SEM of two independent experiments (P1), and five independent experiments (P2 and P3)

\section{Discussion}

Our data demonstrate that the rat beta-cell line, INS1 , produces high levels of IGF-II mRNA, the production of which is controlled by glucose. Multiple IGF-
II mRNAs are expressed in INS-1 cells with the predominant mRNA of about $3.6 \mathrm{~kb}$. The IGF-II gene in humans and rodents comprises multiple transcription products resulting from alternative promoter usage, differential splicing, and multiple polyadenylation signals. In rodents the major transcripts are 3.8 , 4.6 , and $3.6 \mathrm{~kb}$ derived from the promoters 1,2 , and 3 , respectively. In newborn rat heart and brain tissues the IGF-II mRNA is transcribed from P3, giving rise to a predominant species of $3.6 \mathrm{~kb}$ with a small transcript of $1.2 \mathrm{~kb}$. Also, a $4.6 \mathrm{~kb}$ transcript derived from $\mathrm{P} 2$ is present in these tissues. In the rat hepatocyte cell line BRL3A IGF-II mRNA is derived from $\mathrm{P} 1, \mathrm{P} 2$, and $\mathrm{P} 3$ with a preference for $\mathrm{P} 3$. It could be said that in rat cell lines and tissues $P 3$ is the most active promoter [37]. Consistent with this, we found that IGF-II P3 is by far more active than IGF-II P1 and P2 in INS-1 cells when tested in transient transfection assays, indicating that the predominant $3.6 \mathrm{~kb}$ mRNA is transcribed from P3. The fold increase of IGF-II mRNA from low to high glucose concentrations in this cell line, was almost identical to the fold increase of IGF-II P3 expression (luciferase activities) in the transfected INS-1 cells cultured at the two glucose concentrations (approximately threefold). This observation, along with the high stability of IGF-II mRNA at high and low glucose concentrations, suggests that the glucose-induced IGF-II gene up-regulation in this cell line, at least in part, is transcriptionally controlled. The IGF-II gene, therefore, falls into the group of genes that are regulated by glucose, such as insulin and the enzymes that are involved in glucose and fatty acid metabolism i.e., acetyl CoA carboxylase and fatty acid synthase. The effects of glucose on acetyl CoA carboxylase (ACC) [46] and pyruvate kinase [47] in INS-1 cells, and ACC and fatty acid synthase in adipocyte tissue [48] have been shown to be mimicked by glucose 6-phosphate, the first product in the glucose metabolism pathway. The effect of glucose on these genes was quite rapid and a net increase in mRNA level could be detected at $4 \mathrm{~h}$ following incubation at high glucose. A glucose-response element in the promoter of L-type pyruvate kinase gene [49], and similar motifs in the promoter 2 of the ACC gene have been demonstrated [46]. The glucose-induced IGF-II mRNA increase differs from those of $\mathrm{ACC}$ and pyruvate kinase in two respects. Firstly, the induction has a long lag period $(24 \mathrm{~h})$, and secondly, no sequence corresponding to this "glucose-response element" could be identified in the rat IGF-II P3 [50]. These findings suggest the presence of an intermediary glucose-responsive molecule(s) involved in the IGF-II gene up-regulation by glucose, yet to be determined. Recently, it has been reported that part of the glucose-induced insulin gene expression is through the increase in nuclear transcription factors that bind the Far element, present in the rat insulin I 
gene promoter [51]. No such element was identified in the rat IGF-II P3.

Glucose-induced beta-cell activities, such as insulin secretion, are believed to be mediated by a rise in cyclic AMP, and/or activation of protein kinase $\mathrm{C}$ $[43,44,52]$. To assess whether the same mechanism is involved in glucose-induced IGF-II gene expression, the levels of IGF-II mRNA in INS-1 cells in the presence of forskolin, a cyclic AMP increasing agent, or PMA, a protein kinase C activator were determined. We found that the glucose-induced IGF-II gene expression in this cell line is not mediated by the two transducing systems. These observations differ from the regulation of IGF-II gene expression in other systems. Cyclic AMP increasing agents in human fetal pancreas islet-like cell clusters [23], human fetal adrenal $[53,54]$, and rat thyroid follicular cells [55] increase the IGF-II mRNA levels, and PMA causes the reduction of basal levels of IGF-II mRNA in human fetal adrenal cells [54]. These findings suggest that IGF-II gene regulation could vary depending on the developmental stage and specificity of the tissues.

Insulin and IGF-II in rats are tandemly located on the rat chromosome 1 [27]. This, along with the finding that IGF-II could be detected only in the beta cells of adult rat, human, and dog pancreatic islets [19], has raised the assumption that the two genes are co-regulated. Indeed, recently, a parallel regulation of the two tandemly located genes, IGF-II and H19 (H19 expresses an mRNA to which no protein has been assigned), was reported in cultured human fetal adrenal cells [53]. The comparison of insulin and IGF-II gene expression under different culture conditions in this beta-cell model argues against this hypothesis. Firstly, the glucose concentration for optimal gene induction is different for the two genes. During long-term treatment, at $5 \mathrm{mmol} / 1$ glucose the insulin gene was highly expressed, while IGF-II was expressed at basal levels. Conversely, at $15 \mathrm{mmol} / \mathrm{l}$ of glucose where the IGF-II gene was maximally expressed, the insulin gene was markedly down-regulated. Secondly, forskolin exerts opposing effects on insulin and IGF-II gene expression. Cyclic AMP increased insulin mRNA levels in INS-1 cells, both at low and high glucose concentrations, consistent with the previous findings in normal islets [56] and betacell lines $[57,58]$. However, it strongly inhibited the glucose-induced IGF-II mRNA increase. Thirdly, although PMA increased the insulin mRNA level at high glucose concentrations (as has been previously demonstrated in a clonal hamster beta-cell line, HITT15 [57]) it had no detectable effects on the IGF-II gene expression in this cell line.

Glucose, at high concentrations, exhibited negative effects on insulin mRNA accumulation and on the IGF-II P3-luciferase expression in the transient transfection assay during the long-term (48-h and longer) treatment. The threshold of the inhibitory glucose concentration for the two genes, however, varied greatly $(10$ and $25 \mathrm{mmol} / 1$ for insulin and IGF-II, respectively). This phenomenon, reminiscent of "glucose toxicity" $[59,60]$ was observed for other genes in this cell line (data not shown). The negative effects of high glucose concentration on insulin gene expression during long-term exposure have been demonstrated previously in the HIT-T15 cell line [61]. The mechanism of this "glucose toxicity" was determined to be partly due to a change in the ability of a glucose-sensitive transcription factor to interact with the insulin gene promoter. Whether the same mechanism is effective in this broad range of "genesilencing" activities of high glucose concentrations in INS- 1 cells remains to be determined.

IGF-II is defined as an autocrine growth factor, and recently its role as a tumour progression factor of beta cells [62] and other cell types [63], when expressed at abnormally high levels, has been reported. Although the direct involvement of the endogenous IGF-II in INS-1 cell proliferation remains to be determined, the effects of glucose on IGF-II mRNA upregulation and DNA synthesis (induction of thymidine uptake) are superimposable both in time and concentration. This is also the case when the effects of PMA and forskolin on IGF-II mRNA and DNA synthesis are compared. Whether this is a cause-andeffect relationship is under investigation; however, it clearly indicates that IGF-II gene activation and DNA synthesis in this cell line are regulated in parallel.

Acknowledgements. The authors would like to express their gratitude to Dr. M. Prentki and Dr. M. Binoux for their intellectual participation and their interest in this work.

\section{References}

1. Rechler MM, Nissley SP (1990) Insulin-like growth factors. In: Sporn MB, Roberts AB (eds) Peptide growth factors and their receptors. Springer, Berlin Heidelberg New York, pp 263-346

2. Lerenzo M, Valverde AM, Teruel T, Benito M (1993) IGF-I is a mitogen involved in differentiation-related gene expression in fetal rat brown adipocytes. J Cell Biol 123: 1567-1575

3. Prisell PT, Edwall D, Lindblad JB, Levinovitz A, Norstedt G (1993) Expression of insulin-like growth factors during bone induction in rats. Calif Tissue Int 53: 201-205

4. Near SL, Whalen RL, Miller JA, Ishii DN (1992) Insulinlike growth factor II stimulates motor nerve regeneration. Proc Natl Acad Sci 89: 11716-11720

5. Florini JR, Magri KA, Ewton DZ, James PL, Grindstaff K, Rotwein PS (1991) "Spontaneous" differentiation of skeletal myoblast is dependent upon autocrine secretion of insulin-like growth factor II. J Biol Chem 266: 15917-15923

6. Remacle-Bonnet M, Garrouste F, ElAtiq F, Roccabianca M, Marvaldi J, Pommier G (1992) Des-(1-3)-IGF-I, an insulin-like growth factor analog used to mimic a potential 
IGF-II autocrine loop, promotes the differentiation of human colon-carcinoma cells. Int J Cancer 52: 910-917

7. Humbel R (1990) Insulin-like growth factors I and II. Eur J Biochem 190: 445-462

8. Bang P, Hall K (1992) Insulin-like growth factors as autocrine paracrine hormones. In: Schofield PN (ed) The insulin-like growth factors. Structure and functions. Oxford University Press, Oxford, pp 151-168

9. Daughaday W (1990) Editorial:The possible autocrine/ paracrine and endocrine roles of insulin-like growth factors of human tumors. Endocrinology 127: 1-4

10. Perdue JF, LeBon TR, Kato J, Hampton B, Fujita-Yamaguchi $Y$ (1991) Binding specificities and transducing functions of the different molecular forms of insulin-like growth factor-II (IGF-II) on IGF-I receptors. Endocrinology 129: 3101-3108

11. Hauguel-de Maouzon S, Khan CR (1991) Insulin-like growth factor-mediated phosphorylation and protooncogene induction in Madin-Darby canine kidney cells. Mol Endocrinol 5: 51-60

12. Sakano K-I, Enjoh T, Numata F et al. (1991) The design, expression and characterization of a human insulin-like growth factor II (IGF-II) mutants specific for either the IGF-II/mannose-6-phosphate receptor or IGF-I receptor. J Biol Chem 266: 20626-20635

13. Steiner DF, Chan SJ, Welsh JM, Kwok SCM (1985) Structure and evolution of the insulin gene. Ann Rev Genetics 19: 463-484

14. Bell GI, Gerhard DS, Fong NM, Sanchez-Pescador R, Rall LB (1985) Isolation of human insulin-like growth factor genes: insulin-like growth factor II and insulin genes are contiguous. Proc Natl Acad Sci 82: 6450-6454

15. DeChiara TM, Efstradiatis A, Robertson EJ (1990) A growth deficiency phenotype in heterozygous mice carrying insulin-like growth factor II gene disrupted by targeting. Nature 345: 78-80

16. Stylianopoulou F, Efstradiatis A, Herbert J, Pintar J (1988) Pattern of the insulin-like growth factor-II gene expression during rat embryogenesis. Development 103: 497-506

17. Stylianopoulou F, Herbert J, Soares MB, Efstradiatis A (1988) Expression of the insulin-like growth factor-II gene in the choroid plexus and leptomeninges of the adult rat central nervous system. Proc Natl Acad Sci 85: 141-145

18. Höög A, Grimelius L, Falkmer S, Sara VR (1993) A high molecular weight IGF-2 immunoreactive peptide (proIGF-2?) in the insulin cells of the islets of Langerhans in pancreas of man and rat. Regulatory Peptides 47:275-283

19. Maake C, Reinecke M, (1993) Immunohistochemical localization of insulin-like growth factor 1 and 2 in the encocrine pancreas of rat, dog, and man, and their coexistence with classical islet hormones. Cell Tissue Res 273: 249-259

20. Romanus JA, Rabinovitch A, Rechler MM (1985) Neonatal rat islet cell cultures synthesize insulin-like growth factor-I. Diabetes 34: 696-702

21. Hill DJ, Frazer A, Swenne I, Wirdnam PK, Milner DG (1987) Somatomedin-C in human fetal pancreas. Cellular localization and release during organ culture. Diabetes 36 : $465-471$

22. Scharfmann R, Corvol M, Czernichow P (1989) Characterization of insulin-like growth factor 1 produced by fetal rat pancreatic islets. Diabetes 38: 686-690

23. Miettinen PJ, Otonkoski T, Voutilainen R (1993) Insulinlike growth factor-II and transforming growth factor- $\alpha$ in developing human fetal pancreatic islets. J Endocrinol 138: $127-136$

24. Hogg J, Han VKM, Clemmons DR, Hill DJ (1993) Interaction of nutrients, insulin-like growth factors (IGFs) and
IGF-binding proteins in the regulation of DNA synthesis by isolated fetal rat islets of Langerhans. J Endocrinol 138: $401-412$

25. Hansson H-A, Edwall D, Löwenadler B, Norstedt G, Paleus S, Skottner A (1988) Insulin-like growth factor I in the pancreas of normal and diabetic adult rats. Acta Physiol Scand 132: 569-576

26. Billestrup N, Nielsen $\mathrm{JH}$ (1991) The stimulatory effect of growth hormone, prolactin, and placental lactogen on $\beta$ cell proliferation is not mediated by insulin-like growth factor-I. Endocrinology 129: 883-888

27. Frunzio R, Chiariotti L, Brown AL, Graham DE, Rechler MM, Bruni CB (1986) Structure and expression of the rat insulin-like growth factor-II (rIGF-II) gene. J Biol Chem 261: 17138-17149

28. Soares MB, Turken A, Ishii D et al. (1986) Rat insulin-like growth factor II gene: a single gene with two promoters expressing a multitranscript family. J Mol Biol 192: 737752

29. Asfari M, Janjic D, Meda P, Li G, Halban PA, Wollheim CB (1992) Establishment of 2-mercaptoethanol-dependent differentiated insulin-secreting cell lines. Endocrinology 130: $167-178$

30. Asfari M, Bréant B, Boissard C, Rosselin G (1992) Effect of glucose concentration on insulin and "glucose-sensor" gene expression in INS-1 cells. Diabetologia 35 [Suppl 1]:A13 (Abstract)

31. Asfari M, De W, Postel-Vinay M-C, Czernichow P (1995) Expression and regulation of growth hormone $(\mathrm{GH})$ and prolactin (PRL) receptors in a rat insulin producing cell line (INS-1). Mol Cell Endocrinol 107: 209-214

32. Auffray C, Rougeon F (1980) Purification of mouse immunoglobulin heavy messenger RNA from total myeloma tumor RNA. Eur J Biochem 107: 303-314

33. Le Bouc Y, Noguiez P, Sondermeijer P, Dreyer D, Girard F, Binoux M, (1987) A new $5^{\prime}$-non-coding region for human placental insulin-like growth factor II mRNA expression. FEBS Lett 222: 181-185

34. Ullrich A, Shine J, Chirgwin J et al. (1977) Rat insulin genes: construction of plasmids containing the coding sequence. Science 196: 1913-1919

35. Alonso S, Minty A, Bourlet Y, Buckingham M (1986) Comparison of three actin-coding sequences in the mouse; evolutionary relationships between the actin genes of warmblooded vertebrates. J Mol Evol 23: 11-22

36. Chan Y-L, Gutell R, Noller HF, Wool I (1984) The nucleotide sequence of a rat $18 \mathrm{~S}$ ribosomal ribonucleic acid gene and a proposal for the secondary structure of $18 \mathrm{~S}$ ribosomal nucleic acid. J Biol Chem 259: 224-230

37. Holthuizen PE, Cleutjens CBJM, Veenstra GJC, van der Lee FM, Koonen-Reemst AMCB, Sussenbach JS (1993) Differential expression of the human, mouse, and rat IGFII genes. Regul Pept 48: 77 -89

38. Le Bail O, Schmidt-Ullrich R, Israël A (1993) Promoter analysis of the gene encoding the $\mathrm{I} \varkappa \mathrm{B}-\alpha / \mathrm{MAD} 3$ inhibitor of NF- $x$ B: positive regulation by members of the rel/NF- $x$ B family. EMBO J 12: 5043-5049

39. Binoux M, Seurin D, Lassarre C, Gourmelen M (1984) Preferential measurement of insulin-like growth factor (IGF)I-related peptides in serum with the aid of IGF binding proteins (IGF BPs) produced by rat liver in culture. Estimation of IGF BP levels. J Clin Endocrinol Metab 59: 453-470

40. Binoux M, Lassarre C, Gourmelen M (1986) Specific assay for insulin-like growth factor (IGF) II using the IGF binding proteins extracted from human cerebrospinal fluid. J Clin Endocrinol Metab 63: 1151-1155 
41. Fagot D, Buquet-Fagot C, Mester J (1991) Antimitogenic effects of dexamethasone in chemically transformed mouse fibroblasts. Endocrinology 129: 1033-1041

42. Bonner-Weir S, Smith F (1994) Islet cell growth and the growth factors involved. Trends Endocrinol Metab 5: 60-64

43. Prentki M, Matschinsky FM (1987) $\mathrm{Ca}^{2+}$, cyclic AMP, and phospholipid-derived messengers in coupling mechanisms of insulin secretion. Physiol Rev 67: 1158-1248

44. Arkhammar P, Nilsson T, Welsh M, Welsh N, Berggren P-O (1989) Effects of protein kinase $C$ activation on the regulation of the stimulus-secretion coupling in pancreatic beta cells. Biochem J 264: 207-215

45. Zarrilli R, Casola S, Conti A, Bruni CB, Colantuoni V (1993) Extinction of insulin-like growth factor II gene expression in intratypic hybrids of rat liver cells. Mol Endocrinol 7: 131-141

46. Brun T, Roche E, Kim K-H, Prentki M (1993) Glucose regulates acetyl-CoA carboxylase gene expression in a pancreatic $\beta$-cell line (INS-1). J Biol Chem 268: 18905-18911

47. Marie S, Diaz-Guerra M-J M, Miquerol L, Khan A, Iynedjian P (1993) The pyruvate kinase gene as a model for studies of glucose-dependent regulation of gene expression in the endocrine pancreatic $\beta$-cell type. J Biol Chem 268: 23881-23890

48. Foufelle F, Gouhot B, Pégorier J-P, Perdereau D, Girard J, Ferré P (1992) Glucose stimulation of lipogenic enzyme gene expression in cultured white adipose tissue. J Biol Chem 267: 20543-20546

49. Bergot M-O, Diaz-Guerra M-J M, Puzenat N, Reymondjean M, Kahn A (1992) Cis-regulation of the L-type pyruvate kinase gene promoter by glucose, insulin and cyclic AMP. Nucleic Acid Res 20: 1871-1878

50. Ikejiri K, Ueno T, Matsuguchi Tet al. (1990) Primary structure of the insulin-like growth factor II gene region. Biochim Biophy Acta 1049 (3):350-353

51. German MS, Wang J (1994) The insulin gene contains multiple transcriptional elements that respond to glucose. Mol Cell Biol 9: 3253-3259

52. Charles MA, Lawecki J, Pictet R, Grodski GM (1975) Insulin secretion. Interrelationships of glucose, cyclic adenosine $3^{\prime}-5^{\prime}$-monophosphate, and calcium. J Biol Chem 250: 61346140
53. Voutilainen R, Ilvesmäki V, Ilana A, Rachmilewitz J, DeGroot N, Hochberg A (1994) Parallel regulation of parentally imprinted H19 and insulin-like growth factor-II genes in cultured human fetal adrenal cells. Endocrinology 134: 2051-2056

54. Ilvesmäki V, Blum WF, Voutilainen R (1993) Insulin-like growth factors-II in human fetal adrenals: regulation by ACTH, protein kinase $\mathrm{C}$ and growth factors. J Endocrinol 137: $533-542$

55. Maciel RMB, Moses AG, Villone G, Tramontano D, Ingbar SH (1988) Demonstration of the production and the physiological role of insulin-like growth factor II in rat thyroid follicular cells in culture. J Clin Invest 82: 1546-1553

56. Hammonds P, Schofield P, Ashcroft SJH, Sutton R, Gray DWR (1987) Regulations and specificity of glucose-stimulated insulin gene expression in human islets of Langerhans. FEBS Lett 223: 131-137

57. Hammonds P, Schofield PN, Ashcroft SJH (1987) Glucose regulates preproinsulin messenger RNA levels in a clonal simian virus 40-transformed B cells. FEBS Lett 213: 149154

58. Nielsen DA, Welsh M, Casadaban MJ, Steiner DF (1985) Control of insulin gene expression in pancreatic $\beta$-cells and in an insulin producing cell line, RIN-5F cells. I. Effects of glucose and cyclic AMP on the transcription of insulin mRNA. J Biol Chem 260: 13585-13589

59. Robertson RP, Olson LK, Zhang H-J (1994) Differentiating glucose toxicity from glucose desensitization: a new message from the insulin gene. Diabetes 43: 1085-1089

60. Yki-Järvinen H (1992) Glucose toxicity. Endocr Rev 13: 415-431

61. Olson LK, Redmon JB, Towle HC, Robertson RP (1993) Chronic exposure of HIT cells to high glucose concentrations paradoxically decreases insulin gene transcription and alters binding of insulin gene regulatory protein. $J$ Clin Invest 92: $514-519$

62. Christofori G, Naik P, Hanahan D (1994) A second signal supplied by insulin-like growth factor II in oncogene induced tumorigenesis. Nature 369: 414-417

63. Rogler C, Yang D, Rossetti L et al. (1994) Altered body composition and increased frequency of diverse malignancies in insulin-like growth factor-II transgenic mice. J Biol Chem 19: 13779-13784 